\title{
Intercultural Communication In Global Business: An Analysis Of Benefits And Challenges
}

\author{
Melvin C. Washington, Howard University, USA \\ Ephraim A. Okoro, Howard University, USA \\ Otis Thomas, Bowie State University, USA
}

\begin{abstract}
The twenty-first century business environment is expanding and increasingly attracting the interest of countries from developed and developing nations of the world. As countries of the world become increasingly interdependent and interconnected because of global market and diverse consumer needs, it is critically important that participating countries and their organizations understand and appreciate one another's cultural differences in order to ensure growth and sustainability in international business. Recent studies have traced the failure of some international business ventures to three significant factors: lack of intercultural skills and competence, inability to communicate effectively at a global level, and failure to practice acceptable etiquette in business negotiations. Therefore, businesses from different countries need to appreciate the importance of understanding the cultures and values of their counterparts as well as develop intercultural communication sensitivity and decorum. This paper then is an attempt toward analyzing the significance and role of intercultural communication and etiquette in international business. Recommendations for appropriate practices and acceptable conducts among nations are provided.
\end{abstract}

Keywords: International Business; Intercultural Communication; Etiquette; Business Negotiation; Multicultural Competence; Cultural Diversity

\section{INTRODUCTION}

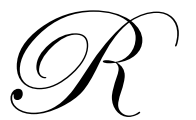

ecent events and developments have repositioned etiquette and intercultural communication as fundamental topics requiring critical analysis in light of the increasing number of countries participating in global business transactions, various strategic international alliances, and multinational joint ventures. As organizations from developed and developing nations struggle to establish their ethical identity, business etiquette, and engage in intercultural communication, the business environment becomes challenging and complex as a result of differing standards, expectations, and language patterns. International business etiquette as defined by Chaney and Martin (2007) refers to the manners and behavior considered acceptable behavior in internationally social and business situations. In social setting, proper social behavior includes cultural differences in making introductions, exchanging business cards, acknowledging position and status, communicating interculturally, dining practices, tipping etiquette, giving gifts, and traveling. In international business situations, how competent and competitive firms are both domestically and internationally and how they effectively communicate to their stakeholders will determine how successful a firm is internationally. Furthermore, as the authors expound, building global business relationships depends on the innate ability to learn about other cultures and proper training to help a person adjust once he or she is in another culture. In addition, it refers to the customs and regulations dealing with diplomatic courtesies expected in official negotiations with persons in various cultures. Chaney and his colleague explain that when interacting with colleagues or counterparts of other cultures in a business or marketing context, it is important to know their customs to ensure that an intended meaning is not conveyed in order to avoid unintentionally offending them. Furthermore, other scholars ( O'Roourke, 2010; Cardon 
\& Scott, 2003; Brett, 2001) see global business etiquette as a natural outgrowth of business globalization, which in many significant ways complicate the way people from different backgrounds in organizational and learning contexts behave in business situations. They explain that employees who work globally should be trained in technical knowledge, such as import and export laws of other countries, comparative management styles, and business protocol, etiquette, and ethics.

As today's marketplace becomes increasingly global, modern business now demands that people travel to foreign countries, communicate effectively with foreign clients, colleagues, and customers in efforts to take advantage of the opportunities of a culturally diverse marketplace environment. Chaney and Martin (2007) point out that many businesses are beginning to have a global mindset by sourcing, producing, importing, or exporting their products. As a result, addressing the full complexity of intercultural communication has gained substantial importance in the international business arena. Specifically, international business etiquette (the expected rules of behavior for intercultural communication) has become progressively more complex. In fact, Bovee and Thill (2010) argue that learning the skills of proper etiquette on an international level is one of the most important elements for business success and growth. The authors note that some behavioral rules are formal and specifically articulated, while others are informal and learned over time, thus influencing the overall behavior of most people in a society most of the time. As businesses begin to appreciate and respect cultural differences, they develop a better understanding of why people act in certain ways and give them a better understanding on how they should act while conducting business. Similarly, O'Rourke (2010) note that the most common factors contributing to failure in international business assignments is the inability to understand and adapt to foreign ways of thinking and acting as opposed to technical or professional incompetence. As participation in the global marketplace flourishes, employees are being asked to do more. Bovee and Thill (2010) maintain that supervisors face the challenge of acknowledging that expected behaviors of diverse employees, multi-national teams face the challenge of working together closely, and businesses are challenged to peacefully negotiate with international business partners. Thus, learning and understanding more about conducting international business has become especially challenging.

Carte \& Fox (2008) argue that the challenge in international business is anticipating and understanding cultural differences in international business etiquette and being able to adapt accordingly is the foundation of any successful international business. Even though a successful international business hedges largely on how well they behave as business agents in a foreign culture, little effort has been assigned to understanding global business etiquette and its role in international business relationships. The authors maintain that customers, shareholders and the media lose faith and interest in businesses that project an inconsistent image; hence they continually strive to present themselves to the outside world as a united entity with a single set of beliefs. However, this becomes increasingly difficult, for the larger a business becomes, the more international they develop into as they cross national borders in search of growth.

This study therefore attempts to explicate the current opportunities, challenges, and benefits in understanding and applying proper international business etiquette in an increasingly globally diverse workforce. Followed by the introduction, specifically, the paper examines the current literature on global business etiquette in six countries that do business with each other regularly.

\section{REVIEW OF RELATED LITERATURE}

Carte \& Fox (2008) explain that with the tremendous surge in global trade, it is vital to learn about the different cultures and behaviors around the world, in order to reduce the risk of failure. Effectively adapting business etiquette to businesspersons from other countries requires both knowledge about the culture and the ability and motivation to adapt to different behaviors. For example, the giant retailer Wal-Mart learned this lesson the hard way when they tried to expand into Germany. Store clerks resisted Wal-Mart's policy of always smiling at customers because customers sometimes misinterpreted smiling as flirting. Eventually, because of a number of other cultural missteps, Wal-Mart had to leave the German market (Bovee and Thill, 2010). Thus, becoming knowledgeable about different countries business etiquette is the key to having good business relationships with individuals and businesses in other countries. The following is a review of the current research on the business behavior/etiquette in four countries (China, England, Germany, and Japan) that conduct business in the United States on a regular basis. 


\section{Chinese Business Etiquette}

Earley (1997) notes that business etiquette in China is the most reserved and most unlike the United States, out of the six countries included in this review. To the United States businessperson, a personal relationship can be separated from business. Friendships are formed quickly formed and dissolved. Hence, many view the U.S. business relationship as shallow and short-termed, while business relationships in China are viewed as lifetime commitments (Martin \& Chaney, 2006). Chinese business etiquette is directly related to the Chinese sensitivity to face. TingToomey \& Kurogi (1998) and Earley (1997) refer to face as an evaluation of a person's credibility and self image. The hundreds of phrases in the Chinese language describing face demonstrate the sophistication of face and how it relates to communication behaviors (Cardon \& Scott, 2003), such as global business etiquette. The authors further note that Chinese businesspersons employ a number of communication strategies designed to receive face or give face to others, such as indirectness, intermediaries, praising, requests, and shaming. In order to save face, they often try indirectness by avoiding public confrontations. The use of intermediaries avoids direct confrontation, especially in conflict situations, such that a contact should always be established before representatives of business are sent to China. They believe in a win-win negotiation strategy that allows both sides to be winners to increase the strength of the relationship. In addition, Cardon and his colleague explained that Chinese businesspersons employ praise to recognize status and position. For example, they often times make direct request for favors because this will signal that a business relationship is firm. Finally, Chinese businesspersons employ shame when individuals violate the trust of a relationship.

When conducting business in China or in the United States with a person from China, the rules of business etiquette are controlled and determined by face giving and taking. For example, when giving introductions, remember that the surname comes first and the given name last. The introduction is accompanied by a bow which is uncommon in many other cultures (Chaney \& Martin, 2007). The authors stress that out of concern for their business partners, many times, the handshake is combined with a bow so that each culture shows the other proper respect. Another example of how face influences Chinese business etiquette is the importance of the business card exchange. Chinese business cards represent the person to whom you are being introduced, so it is polite to study the card for a while and then put it down as a sign of respect. Furthermore, Chaney and his colleague note that, as a mark of respect and appreciation, the Chinese examine business cards carefully and make some favorable comments while accepting them. During meetings with Chinese, it is a common practice for them to place business cards of others attending the meeting in front of them on the conference table in order to properly refer to names, ranks, and titles. Usually, both hands are used when presenting and receiving cards, and they position cards strategically so that they can be read easily.

\section{British (England) Business Etiquette}

Business etiquette in England is based on a strong sense of identity and nationalism. The English businessperson tends to be very matter-of-fact and tends to be very deadline oriented in business negotiations (Chaney \& Martin, 2007). Traditions and customs (etiquette) are very important to the English, as they tend to be reserved and expect others to act accordingly. Unlike businesspersons from the U.S., business friendships are not necessary (Morrison et al., 1994). Carte \& Fox (2008) note that because of their individualist culture, like the Americans, they focus on the tasks set out in their job description and think it's normal for a boss to reward individual effort. The English businesspersons' reputation of reserve is well deserved, thus so manifesting itself in their strict adherence to protocol (Martin \& Chaney, 2006) and their ability to confront adversity with courage and strength of character (Harper, 1997). Harper (1997) notes that when conducting business in England, be careful about asking too many personal questions too quickly, partly because it makes them nervous and partly because they are naturally reserved. The author further notes that the English business person, while having excellent manners, has "lousy" people skills.

When conducting business in England, the rules of business etiquette are controlled and determined by the English businesspersons' reserved character and strong sense of identity (Harper, 1997). For example, Martin \& Chaney (2006) explain that conservative attire of excellent quality is important in England when judging dress and appearance. There, as well as, in other European countries, dress is an indication of social and business status, so it is important to dress your best by selecting clothing made of quality fabrics with fine tailoring. In addition, 
accessories should be of high quality and reflect good taste. English inappropriate attire includes sweat suits and tennis shoes, which are viewed as appropriate only for athletic activities. The English businesspersons' negotiation processes also reflect their cultural characteristics; they are very formal and polite and place great value on proper protocol and etiquette (Chaney \& Martin, 2007). In addition, the authors note that the English can be tough and ruthless negotiators and can sometimes appear quaint and eccentric, many times causing other cultures to underestimate their skill. Mole (1997) adds that the English businessperson quickly lose their reserve when their basic assumptions about themselves are challenged.

\section{German Business Etiquette}

Troyanovich (1972) explains that business etiquette in Germany is based on the formal culture of Germany that defines behavioral expectations in great detail, providing its participants with the knowledge of what to do and when to do it. Similarly, Carte \& Fox (2008) noted that German businesspersons respect authority and hierarchical differences. They prefer a hierarchical organizational structure because it avoids uncertainty, where power is ensured within the organization. They are autocrats, who prefer formal communication when conducting business. In addition, they focus on personal achievements and truth and directness are important aspects in business. Tinsley and Woloshin (1974) add that the ideal person is one who can be relied on to do what is expected and whose behavior is predicable, steady, and not much influenced by the opinions of others or by opportunity. Martin and Chaney (2006) also pointed out that more recent research indicates that class status in important to Germans, and even though all people have equal rights under the law, in reality inequalities exist.

The German businesspersons' strict adherence to behavioral expectations is manifested in their standards of business etiquette. For example, being on time for all business and social engagements is more important to the German culture than any of the six countries surveyed in this paper (Axtell, 1998). Being only a few minutes late for meeting can be insulting to German managers and if you are delayed, an explanatory call is expected. In addition, the German sense of punctuality in all situations has been recognized as one of the most consistent stereotypical characteristics of the culture (Tinsley \& Woloshin, 1974). The value of time for the German businessperson is not primarily monetary, however, and there has never been any strong tendency to take time from other activities to increase the amount of time devoted to business affairs. Another example of German business etiquette reflective of their strict adherence to normative behavior is their etiquette for introductions. Martin and Chaney (2006) explain that in Germany, you always use a title when addressing someone until you are told it is okay to use first names. Troyanovich (1972) notes that German businesspersons are very time-conscious and that their preoccupation with punctuality is reflected in the formalized way time is reported to the German public. In agreement, Mole (1999) explains that there is a strong sense that the relationship between the company and the employee is contractual, thus you are paid for so many hours and you work as hard as you can for that period of time.

\section{Japanese Business Etiquette}

Bovee and Thill (2010) explained that Japan's style of business etiquette, as other Asian cultures, is based on their high-context communication. In high-context cultures, people rely less on verbal communication and more on the context of nonverbal actions and environmental setting to convey meaning because so much of the message in carried in cues and "between the lines" interpretation. These contextual differences are apparent in the way businesspersons in Japan approach situations such as decision making and negotiating. For example, negotiators working on business deals in Japan may spend more time building relationships instead of working out contractual agreements. In other words, protecting the business relationship may be as important as making the final business decision. Martin and Chaney (2007) reported that the use of high-context communication can be very confusing to the uninitiated, nonsenitive intercultural businessperson. For example, the Japanese say "yes" for no but indicate whether "yes" is yes or really no by the context. Similarly, (Carte \& Fox, 2008) notes that high context communicators tend to communicate more implicitly. When a Japanese businessperson speaks, they expect the person to interpret what they mean by their knowledge of the cultural values that lie behind the words.

When conducting business meetings in Japan, Bovee and Thill (2010) explain that the rules of etiquette are controlled and determined by their cultural context, the pattern of physical cues, environmental stimuli, and implicit understanding that convey meaning between two members of the same culture. For instance, since the Japanese do 
not use the word "no" and have such subtle verbal and nonverbal cues, businesspersons from other countries must ask a number of questions to be certain they understand the intent of what is being communicated (Brett, 2001). In addition, (Carte \& Fox, 2008) argue that the aim at initial business meeting is to develop a personal trust. Much of the time in these meeting is spent exchanging information about the companies in question before discussing specific business proposals. Another example of how Japan's high-context culture affects their business etiquette is their attitude towards business relationships. As Martin and Chaney (2006) emphasized, building relationships and friendships in Japan is a necessary prerequisite for doing business in their country. Signing a contract in Japan, as well as in other Asian cultures, does not signal a sale or negotiation but a continuation of a relationship with obligations and duties in the future. Indeed, each of these countries has a rich tradition of behaviors and customs that contribute to their standards of business behavior/etiquette and knowing what each expects can aid in improving the business relationships that exists between different cultures.

\section{CONCLUDING REMARKS}

International trade is the outgrowth of globalization which is driven importantly by economic interdependency and advances in technology. But the success in global business ventures will be affected by the inability of countries to understand appropriate business etiquette, customs, and values needed to conduct business among nations of the world. As a number of authors have indicated, an understanding cultural differences as well as intercultural communication competence will not only assist businesses to bridge the communication gap among countries involved in international trade negotiations but will also enable multinational and multicultural managers to manage cultural differences more effectively. Because communication is culture-bound and culture specific, it is critically important that countries involved in international business should devote time to learn, understand, and appreciate the different ethical habits and appropriate etiquette for conducting business transactions in order to establish a lasting strategic relationships and alliances. In light of the benefits and challenges of globalization in the twenty-first century expanded business operations, developing intercultural competence, and developing multicultural sensitivity and global mindset will be instrumental to the success of international business practices, transactions, and negotiations among participating nations.

\section{AUTHOR INFORMATION}

Melvin C. Washington, $\mathrm{PhD}$ is an assistant professor of business and management communication at Howard University. He is the core course coordinator for the business communication program in the School of Business, Department of Marketing. His research focuses on intercultural communication, organizational communication, and critical pedagogy. Address correspondence to Melvin C. Washington, Howard University School of Business, 2600 $6^{\text {th }}$ Street N.W., Washington, D.C. 20059; E-mail: m_c_washington@ @oward.edu.

Ephraim A. Okoro, $\mathrm{PhD}$ is an assistant professor of business communication and marketing at Howard University. His research interests probe the interface between intercultural communication and workforce diversity in the context of globalization. He teaches management/business/marketing communication as well as principles of marketing. Address correspondence to Dr. Ephraim Okoro, Department of Marketing, School of Business, Howard University, 2600 - Sixth Street, NW, Washington, D.C. 20059; E-mail: eaokoro@ howard.edu. Corresponding author.

Otis Thomas, $\mathrm{PhD}$ is an associate professor and chair, Department of Communications and Director of TV/Radio, Bowie State University, Bowie, Maryland. His primary research interests focus on mass and organizational communication. Address correspondence to Otis Thomas, Bowie State University, Department of Communication, Bowie, MD 20715; E-mail: othomas@bowiestate.edu.

\section{REFERENCES}

1. $\quad$ Axtell, R.E. (1998). Gestures. New York: Wiley.

2. Bovee, C. L., \& Thill, J. V. (2010). Business communication today (10th ed.). Boston: Prentice Hall.

3. Brett, J. E. (2001). Negotiating globally: How to negotiate deals, resolve disputes, and make decisions across cultural boundaries. San Francisco: Jossey-Bass. 
4. $\quad$ Budhwar, P. (2001). Doing business in India. International business review, 43 (4), 549-568.

5. Cardon, P.W. \& Scott, J.C. (2003). Chinese business face: Communication behaviors and teaching approaches. Business communication quarterly, 66 (4), $9-22$.

6. Carte, P. \& Fox, C. (2008). Bridging the culture gap: A practical guide to international business communication ( $2^{\text {nd }}$ ed.). Philadelphia: Kogan Page.

7. Chaney, L.H. \& Martin, J.S. (2007). Intercultural business communication (4 ${ }^{\text {th }}$ ed.). Upper Saddle River, NJ: Pearson Prentice Hall.

8. $\quad$ Early, P.C. (1997). Face, harmony, and social structure: An analysis of organizational behavior across cultures. New York: Oxford University Press.

9. Harper, T. (1997) Passport United Kingdom: Your pocket guide to British business, customs, \& etiquette . Dan Rafael, California: World Trade Press.

10. Martin J.S. \& Chaney, L.H. (2006). Global business etiquette: a guide to international communication and customs. Westport, Conn: Praeger Publishers.

11. Mole, J. Mind your manners: Managing business cultures in Europe. London: Nicholas Brealey Publishing.

12. Morrison. T., Conaway, W.A., \& Borden, G.A. (1994). Kiss, bow, or shake hands. Holbrook, MA: Adams Media Corporation.

13. O'Rourke, IV, J. S. (2010). Management Communication (4thth ed., pp. 280-289). Upper Saddle River, NJ: Pearson Prentice Hall.

14. Ting-Toomey, S. \& Kurogi, A. (1998). Facework competence in intercultural conflict: An updated facenegotiation theory. International Journal of Intercultural Relations, 22 (2), $187-225$.

15. Tinsley, R.L. \& Woloshin, D.L. (1974). Approaching German culture: A tentative analysis. Teaching German, 7 (1), 125-136.

16. Troyanovich, J. (1972). American meets German-cultural shock in the classroom. Teaching German, 5 (2), 67-79. 